\title{
REVIEW
}

\section{Pathophysiology of NASH in endocrine diseases}

\author{
Karim Gariani ${ }^{1}$ and François R Jornayvaz@1,2 \\ 'Service of Endocrinology, Diabetes, Nutrition and Therapeutic Patient Education, Geneva University Hospitals and Geneva University, \\ Geneva, Switzerland \\ ${ }^{2}$ Diabetes Center, Faculty of Medicine, University of Geneva, Geneva, Switzerland
}

Correspondence should be addressed to F R Jornayvaz: Francois.Jornayvaz@hcuge.ch

\begin{abstract}
Nonalcoholic fatty liver disease (NAFLD) is the most common cause of chronic liver disease in the industrialized world. NAFLD encompasses a whole spectrum ranging from simple steatosis to nonalcoholic steatohepatitis (NASH) and cirrhosis. The latter can lead to hepatocellular carcinoma. Furthermore, NASH is the most rapidly increasing indication for liver transplantation in western countries and therefore represents a global health issue. The pathophysiology of NASH is complex and includes multiple parallel hits. NASH is notably characterized by steatosis as well as evidence of hepatocyte injury and inflammation, with or without fibrosis. NASH is frequently associated with type 2 diabetes and conditions associated with insulin resistance. Moreover, NASH may also be found in many other endocrine diseases such as polycystic ovary syndrome, hypothyroidism, male hypogonadism, growth hormone deficiency or glucocorticoid excess, for example. In this review, we will discuss the pathophysiology of NASH associated with different endocrinopathies.
\end{abstract}

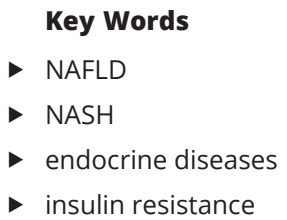

Endocrine Connections (2021) 10, R52-R65

\section{Introduction}

Nonalcoholic steatohepatitis (NASH) is part of a disease spectrum, nonalcoholic fatty liver disease (NAFLD), which ranges from simple steatosis to fibrosis and ultimately cirrhosis $(1,2,3,4)$. NASH is, therefore, a progressive subtype of NAFLD that can result in cirrhosis, hepatocellular carcinoma and liver-related mortality. Importantly, hepatic fibrosis is the only histologic feature of NASH independently associated with long-term overall mortality, liver transplantation and liver-related mortality (5). Validated drugs to treat NASH are still lacking, although numerous studies are underway (6). Interestingly, numerous endocrine diseases other than type 2 diabetes are also associated with NAFLD and NASH $(7,8,9)$. The aim of this review is to present different endocrine diseases that may result in the development of NASH and discuss their underlying pathophysiology.

\section{Epidemiology}

NAFLD is now the most common cause of chronic liver disease in western countries, affecting approximately $30 \%$ of the general population, and its worldwide prevalence continues to increase concurrently due to the growing obesity epidemic (10). As such, NAFLD is projected to become the most common indication leading to liver transplantation in the United States soon (11). The prevalence of NAFLD can reach $90-95 \%$ in obese individuals and affects up to $70 \%$ of patients with type 2 $(12,13,14)$.

The estimation of NASH prevalence at the population level is difficult because the diagnosis requires a liver biopsy, which is infrequently performed. Indirect estimates suggest that NASH affects $3-6 \%$ of the US population, with an increased prevalence in patients with metabolic diseases and obesity. Although often clinically silent, NASH progresses to cirrhosis in approximately $20 \%$

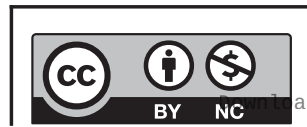

This work is licensed under a Creative Commons Attribution-NonCommercial 4.0 International License. ded from Bioscientifica.com at 04/26/2023 02:09:00PM 
of cases and is associated with increased rates of liverspecific and overall mortality (15).

\section{Diagnosis}

Liver biopsy is the gold standard for the diagnosis of NAFLD (10). NAFLD is defined by the accumulation of fat in the liver with $\geq 5 \%$ of hepatocytes containing visible intracellular triglycerides or steatosis, affecting at least 5\% of the liver volume or weight. NAFLD is a diagnosis of exclusion. Indeed, alcohol consumption should be below $30 \mathrm{~g}$ (=3 units) per day for men and $20 \mathrm{~g}$ (=2 units) per day for women. As a remainder, one unit of alcohol $(=10$ $\mathrm{g})$ is defined as 1 glass of beer ( $25 \mathrm{cL}), 1$ glass of wine (20 cL) or 1 glass of spirit (3 cL). Other diseases have to be considered before the diagnosis of NAFLD/NASH can be made, such as autoimmune liver disease, viral hepatitis infection, hemochromatosis, Wilson's disease, or drug consumption (16). Simple hepatic steatosis can progress to NASH if the causative factors persist. NASH is characterized morphologically by steatosis, ballooning hepatocytes, inflammation, with or without fibrosis. NASH itself can continue to progress to cirrhosis and hepatocellular carcinoma $(17,18)$.

NAFLD can be considered as the hepatic manifestation of the metabolic syndrome (3). The Metabolic Syndrome is defined by the presence of any three of the five following risk factors: elevated waist circumference, elevated triglycerides $(\geq 1.7 \mathrm{mmol} / \mathrm{L})$, reduced HDLcholesterol $(<1.0 \mathrm{mmol} / \mathrm{L}$ in males and $<1.3 \mathrm{mmol} / \mathrm{L}$ in females), elevated blood pressure (systolic $\geq 130$ and/or diastolic $\geq 85 \mathrm{mmHg}$ ) and elevated fasting glucose $(\geq 100 \mathrm{mg} / \mathrm{dL})(3,19,20)$.
Whereas liver biopsy is required for the diagnosis of NASH, NAFLD can also be evaluated non-invasively by imaging techniques such as ultrasound, CT or MRI. Transient elastography (e.g. FibroScan) is being widely used combined with different scores, such as NAFLD fibrosis score (NFS) or Fibrosis-4 (FIB4) index, to better predict the severity of hepatic injury. FibroScan has a sensitivity of $85 \%$ for detecting advanced fibrosis and 92\% for detecting cirrhosis (21). Current standard of care regarding NAFLD/NASH diagnosis is reviewed elsewhere $(4,10,15,16,22)$.

\section{Etiology}

As mentioned earlier, NAFLD is a diagnosis of exclusion, so its workup must exclude other causes such as alcohol consumption, hepatitis B and C infection, drug abuse, autoimmune liver disease, hemochromatosis and Wilson's disease.

The principal risk factors to develop NAFLD and $\mathrm{NASH}$ are the presence of insulin resistance and obesity. However, NAFLD and NASH are associated with other extrahepatic manifestations, adding to the burden of disease. These manifestations notably include obstructive sleep apnea, hypertension, dyslipidemia, gut microbiota alterations, genetic predisposition (notably polymorphisms in PNPLA3 and TM6SF2 genes), sedentary lifestyle, and consumption of certain foods (e.g. fructose, saturated fatty acids, overconsumption of carbohydrates leading to de novo lipogenesis) (2, 13, 23, 24, 25, 26). Nevertheless, some endocrine diseases are also associated with NAFLD and NASH (Table 1), and their pathophysiology will be discussed.

Table 1 Endocrine causes of NAFLD.

\begin{tabular}{|c|c|c|}
\hline Hormone & Gland of origin & Example of disease \\
\hline Cortisol & $\begin{array}{l}\text { - Pituitary gland (ACTH) } \\
\text { - Adrenal gland } \\
\text { (cortisol) }\end{array}$ & $\begin{array}{l}\text { - Cushing's disease } \\
\text { - Cushing's syndrome } \\
\text { - Exogenous corticoid administration }\end{array}$ \\
\hline Thyroxine (T4) & $\begin{array}{l}\text { - Pituitary gland (TSH) } \\
\text { - Thyroid gland (free T4) }\end{array}$ & $\begin{array}{l}\text { - Primary hypothyroidism (thyroid disease) } \\
\text { - Secondary hypothyroidism (pituitary (TSH) or hypothalamic disease (TRH)) }\end{array}$ \\
\hline Growth hormone (GH) & $\begin{array}{l}\text { - Pituitary gland }(\mathrm{GH}) \\
\text { - Ectopic secretion }\end{array}$ & $\begin{array}{l}\text { - Acromegaly (pituitary adenoma (GH) or hypothalamic mass (GHRH)) } \\
\text { - Ectopic secretion of GHRH or GH (Bronchial carcinoid, pancreatic islet-cell } \\
\text { tumor, small cell lung cancer, adrenal adenoma, medullary thyroid carcinoma, } \\
\text { pheochromocytoma) } \\
\text { - Growth hormone deficiency }\end{array}$ \\
\hline Testosterone & - Testicles & $\begin{array}{l}\text { - Primary hypogonadism (congenital abnormalities, acquired diseases) } \\
\text { - Secondary hypogonadism (pituitary disease (LH) or hypothalamic disease } \\
(\mathrm{GnRH}) \text { ) }\end{array}$ \\
\hline Prolactin & - Pituitary gland & $\begin{array}{l}\text { - Micro or macroprolactinoma } \\
\text { - Stalk effect }\end{array}$ \\
\hline
\end{tabular}


and increased intestinal permeability, altogether leading

\section{General pathophysiology of NASH}

The pathophysiology of NAFLD is complex and multifactorial with multiple systemic alterations involved (27). The traditional 'two hits' theory consists of a first 'hit' with intrahepatic accumulation of fatty acids, followed by a second 'hit' including other factors such as oxidative stress or mitochondrial dysfunction. However, this theory has been considered too simplistic to adequately represent the pathogenesis of NAFLD. Therefore, it has been replaced by the 'multiple-parallel hits' model that seems more accurate to represent the process of NAFLD development and progression, where various factors act in parallel and in a synergic manner in subjects with genetic predisposition $(27,28,29)$. This multiple hits hypothesis is based on the concept that genetic and environmental factors associated with dietary habits lead to obesity, insulin resistance development, and alteration of intestinal microbiome (29). Insulin resistance promotes hepatic de novo lipogenesis and adipose tissue lipolysis, leading to an increased flux of fatty acids to the liver (30). Insulin resistance will also lead to adipose tissue dysfunction inducing secretion of inflammatory cytokines (31).

Intrahepatic accumulation of fatty acids will induce the development of several deleterious phenomena such as mitochondrial dysfunction, endoplasmic reticulum stress, oxidative stress and production of reactive oxygen species (32). In addition, the alteration of intestinal microbiome induces an increased production of intestinal fatty acids to the activation of cytokines production such as TNF- $\alpha$ and IL-6 (33). These elements will subsequently lead to a chronic hepatic inflammatory state promoting the development and progression of NAFLD and NASH, as summarized in Fig. 1.

\section{Endocrine causes of NASH}

\section{Type 2 diabetes/insulin resistance}

NAFLD is a major risk factor for the development of type 2 diabetes, most likely because of its strong association with hepatic insulin resistance (34). This is notably due to the fact that some lipid intermediates are more likely to cause hepatic insulin resistance. Indeed, while triglycerides are usually considered inert, other lipids such as diacylglycerols and ceramides have been clearly involved in the development of insulin resistance (1, $3,20,34)$. Both diacyglycerols and ceramides interact with insulin signaling. Whereas ceramides inhibit Akt2 phosphorylation and downstream insulin signaling (2), diacylglycerols activate protein kinase $\mathrm{C} \varepsilon(\mathrm{PKC} \varepsilon$ ) as key pathway responsible for causing NAFLD-associated hepatic insulin resistance (34). Confirmation of this interaction between diacylglycerols, PKCE activation and hepatic insulin resistance has been demonstrated in numerous human and rodent models of NAFLD-associated hepatic insulin resistance $(20,35,36,37,38,39,40,41,42,43$,

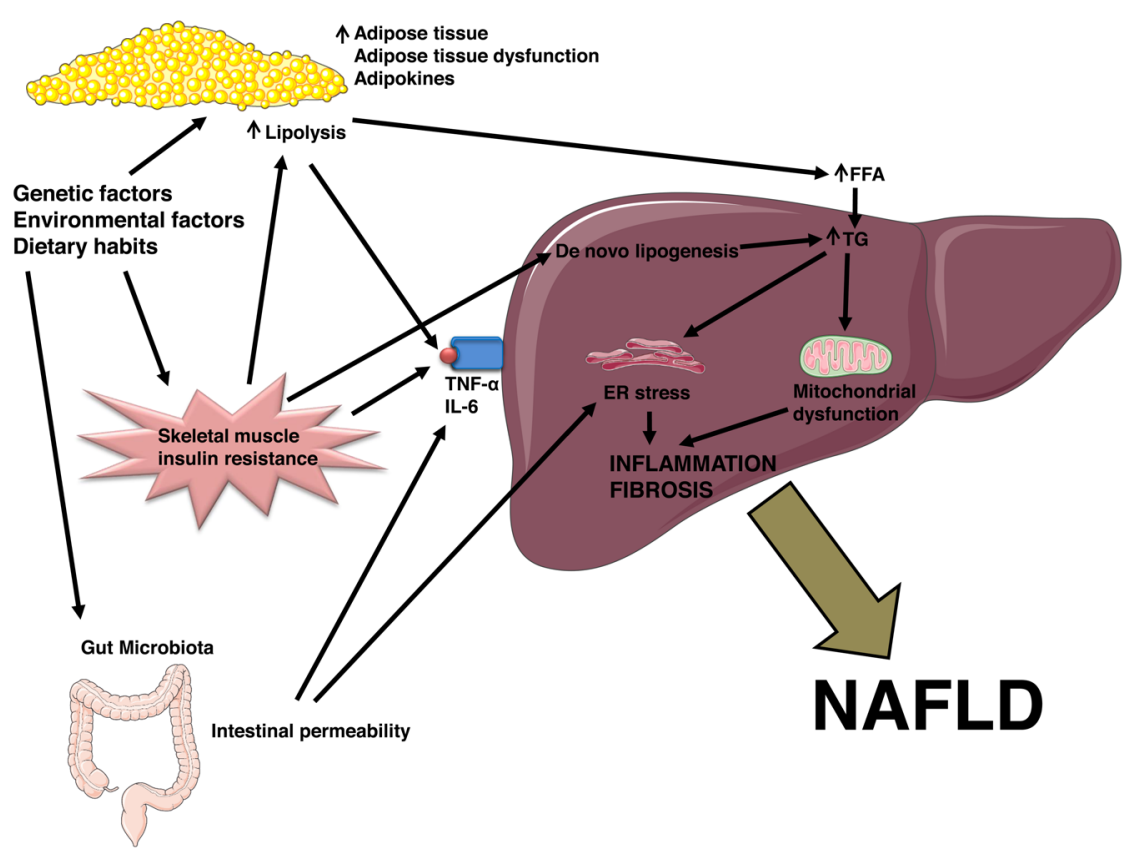

Figure 1

Multiple parallel hits hypothesis for the progression of NAFLD Genetic, dietary and environmental factors lead to the development of insulin resistance, adipocytes proliferation and dysfunction, and alteration of intestinal microbiota. Subsequently, insulin resistance leads to lipolysis, release of adipokines such as TNF- $\alpha$ or IL-6, and stimulates hepatic DNL. As a consequence, the increased flux of hepatic FFAs induces the accumulation of TG, which cause mitochondrial dysfunction and ER stress. Intestinal permeability participates in the activation of hepatic inflammation and ER stress. Altogether these multiple parallel hits lead to the development of NAFLD and its progression to fibrosis and cirrhosis. ER, endoplasmic reticulum; FFA, free fatty acids; IL-6, interleukin 6; NAFLD, non-alcoholic fatty liver disease; TG, triglycerides; TNF- $\alpha$, tumor necrosis factor $\alpha$.

https://ec.bioscientifica.com https://doi.org/10.1530/EC-20-0490 (c) 2021 The authors Published by Bioscientifica Ltd

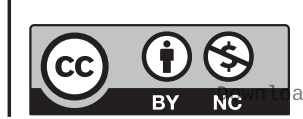

This work is licensed under a Creative Commons Attribution-NonCommercial 4.0 International License. ded from Bioscientifica.com at 04/26/2023 02:09:00PM 
$44,45,46,47,48,49)$. There are multiple causes for the accumulation of diacylglyerols in the liver and PKCE activation resulting in hepatic insulin resistance. Notably, diacylglycerols can accumulate following an increased delivery of chylomicrons remnants observed secondary to increased dietary intake, or depending on diet composition, such as a high-fat or high-fructose diet, or in the case of lipodystrophy or genetic predisposition. Also, increased fatty acids release from adipocytes can result in hepatic accumulation of diacylglycerols, for example in the case of certain gene variants or in cases of insulin resistance. Moreover, skeletal muscle insulin resistance, which can be seen in predisposed or sedentary individuals, can result in de novo lipogenesis, leading to increased hepatic diacylglycerol content. Finally, mitochondrial dysfunction, as discussed earlier, can also result in hepatic accumulation of diacylglycerols. Interestingly, studies in both humans (48) and rodents (38, 50, 51, 52, 53, 54, 53) have clearly demonstrated that compartmentation of diacylglycerols within the hepatocyte is a major factor in determining PKCe activation and hepatic insulin resistance.

The liver is essentially an exocrine gland, secreting bile into the intestine, but can also be considered as an endocrine gland. Indeed, the liver produces some important hormones or hormone precursors, such as insulin-like growth factor 1 (IGF-1), angiotensinogen, thrombopoetin and hepcidin. More recently, numerous hepatokines have been described (54). Among them, the liver produces Fibroblast Growth Factor 21 (FGF21), a hormone also produced by the white adipose tissue. FGF21 has recently emerged as a key regulator in the metabolism of glucose and lipids $(55,56,57)$. FGF21 levels are increased in NAFLD and correlate with hepatic triglyceride content (58), thus FGF21 is considered an emergent biomarker of NAFLD $(59,60)$. In diet-induced obese mice, which already display increased levels of FGF21, suggesting a state of FGF21 resistance, chronic administration of FGF21 not only reverses hepatic steatosis, but also improves insulin sensitivity by notably decreasing hepatic diacylglycerol hepatic content and subsequent PKCe activation (61). Mice lacking Fgf21 (FGF21 KO) have hepatic insulin resistance and increased hepatic glucose production associated with an increase in plasma glucagon levels. FGF21 KO mice are also hypometabolic and display increased fat mass (47). FGF21 may have a potential role as a therapeutic agent for conditions associated with insulin resistance as it has been shown that administration of a recombinant form of this hormone in obese mice and diabetic monkeys improves insulin sensitivity, body weight, lipid profile and even hepatic insulin resistance $(61,62,63,64,65$, 66). Moreover, FGF21 administration could have the potential to modulate inflammation (67). As NASH is associated with inflammation, FGF21 administration, for example by using FGF21 analogs, could be of interest in this context $(68,69)$.

Altogether, these data suggest that the accumulation of ectopic fat in the liver, leading to NAFLD, plays an important pathophysiological role in the development of insulin resistance and type 2 diabetes. Modulation of hepatokines released by the liver, such as FGF21, could represent a therapeutic role in the treatment of NAFLD and NASH.

\section{Polycystic ovary syndrome}

Polycystic ovary syndrome (PCOS) is an endocrine syndrome frequently encountered in young women of childbearing age, with a prevalence of $8-15 \%$ (70). PCOS is best defined by the Rotterdam criteria, that is, oligo/anovulation, clinical and/or biological signs of hyperandrogenism, and polycystic ovaries (by ultrasound) (70). Genome-wide association studies have shown a relationship between PCOS and several genes involved in type 2 diabetes, such as THADA, INSR and HMGA2 (71), and insulin resistance occurs in about half of women with PCOS (72). A meta-analysis of 17 studies revealed that there is a significantly higher risk of NAFLD in women with PCOS than in a control group (OR=2.25, 95\% CI 1.95-2.60). Moreover, this association was independent of obesity and geographic region, but might be correlated with hyperandrogenism (73). A retrospective longitudinal cohort study using a large primary care database in the United Kingdom, evaluating NAFLD rates in 63'120 women with PCOS and 121'064 control women, found that women with PCOS had an increased rate of NAFLD $(\mathrm{HR}=2.23$, 95\% CI 1.86-2.66, $P<0.001$ ), also after adjusting for BMI or dysglycemia (74). The prevalence of NAFLD in women with PCOS varies between 35 and 70\%, depending on the diagnostic method used (75). Regarding the association between PCOS and the histological severity of NAFLD, a study reported that among 200 women with PCOS, 6 of them had biopsy-proven fibrosing NASH. Compared with the 194 of 200 PCOS women who did not undergo biopsy, women with biopsy-documented NASH had lower HDLcholesterol, higher triglycerides, higher fasting insulin, higher aspartate aminotransferase, and higher alanine aminotransferase (76). Conversely, the prevalence of PCOS in women with NAFLD has been shown to reach $71 \%$ in

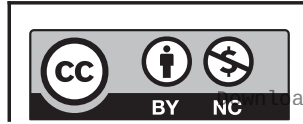

This work is licensed under a Creative Commons Attribution-NonCommercial 4.0 International License. ded from Bioscientifica.com at 04/26/2023 02:09:00PM 
one cohort (77). However, it is not clear whether PCOS is an independent risk factor for NAFLD.

Insulin resistance is a major player in PCOS, promoting hyperandrogenism through an increased release of androstenedione and testosterone (78). Indeed, insulin acts as a co-gonadotropin to increase luteinizing hormone (LH), therefore, stimulating androgens production. A concomitant decrease in sex hormone binding globulin (SHBG) mediated both by insulin resistance and hyperandrogenism further increases the levels of androgens, which leads to a vicious circle increasing insulin resistance. The potential mechanisms leading to insulin resistance in PCOS need to be further defined, but a post receptor defect in the insulin receptor signal transduction has been suggested as there is no structural abnormality in the insulin receptor (79). Hyperandrogenism in PCOS is, therefore, a potential culprit in the development of NAFLD. Indeed, a recent meta-analysis showed that among women with PCOS, those with NAFLD had higher serum total testosterone as well as free androgen index (80). The mechanism behind the association of androgen excess and NAFLD in PCOS has been shown to come from intra-adipose tissue androgen generation, which drives lipotoxicity, notably by increasing adipocyte hypertrophy and fatty acid overspill (81). Among women with PCOS and androgen excess, circulating glycerophospholipids and lysoglycerophospholipids have been identified, and are known as potential biomarkers of NASH $(26,82)$. Interestingly, systemic lipotoxicity is increased after an acute androgen challenge in women with PCOS, but not in BMI-matched controls (81). Finally, women with PCOS, obesity and NAFLD display an increased excretion of $5 \alpha$-reduced steroids (83). The role of $5 \alpha$-reductase is further discussed in the glucocorticoid excess section.

Overall, women with PCOS show a high prevalence of NAFLD, even independently of obesity and dysglycemia. Hyperandrogenism and insulin resistance play a key role in the pathophysiology of PCOS-associated NAFLD, although the exact mechanisms remain elusive. Further studies are needed to better understand the complex endocrine regulations in the interconnections linking PCOS with NAFLD, in order to notably establish whether treatment with anti-androgenic drugs may reduce the risk of NAFLD in women with PCOS.

\section{Hypothyroidism}

Hypothyroidism is a frequent endocrine disorder defined by thyroid hormone insufficiency (84). Primary overt hypothyroidism is defined by an elevated level of thyroid-stimulating hormone (TSH) in association with low serum free thyroxine (T4) levels, while subclinical hypothyroidism is characterized by elevated TSH levels in association with normal levels of T4. Thyroid hormones are involved in various metabolic processes, including body fat distribution, lipid utilization, energy expenditure, and glucose homeostasis. Altered thyroid hormone levels may, therefore, participate in the development of NAFLD (85). Indeed, individuals with hypothyroidism are more at risk of developing components of the metabolic syndrome such as impaired fasting glucose levels, obesity, and hyperlipidemia that are clearly associated with the occurrence of NAFLD, thus suggesting a close link between hypothyroidism and NAFLD (86). A metaanalysis including nearly 13,000 individuals revealed a prevalence of $15-36 \%$ of hypothyroidism among NAFLD patients (87). This association has been confirmed in a single large study including more than 2000 subjects with subclinical or overt hypothyroidism (88).

The potential pathophysiological mechanisms supporting this epidemiological relationship comprise the frequent occurrence of insulin resistance in hypothyroidism, possibly mediated by an increase in the levels of several adipocytokines such as TNF- $\alpha$, IL-1, or leptin; elevated oxidative stress; and increased lipid peroxidation that are often encountered in hypothyroidism and that may lead to the development of insulin resistance $(89,90)$. Interestingly, TSH per se may promote liver de novo lipogenesis. Indeed, the receptor for thyrotropin is expressed on the surface of hepatocytes, where it can be activated by TSH, thereby resulting in stimulation of the peroxisome proliferator-activated receptor- $\alpha$ (PPAR $\alpha)$ pathway that leads to the activation of sterol regulatory element-binding transcription factor 1 (SREBP-1c), which promotes hepatic lipogenesis (90, 91). This mechanism may, in part, explain the observed association of NAFLD and subclinical hypothyroidism (92). Due to shared features between hypothyroidism and the metabolic syndrome, and the tight relationship between NAFLD and the metabolic syndrome, screening for the presence of NAFLD should be considered for individuals with hypothyroidism, in particular when they are also overweight or obese.

Levothyroxine administration has been shown to be associated with reduction of the BMI and the level of serum lipids, thus suggesting a potential beneficial impact on NAFLD (84). In addition, several randomized controlled trials have shown a reduction in liver enzyme levels and hepatic fat content after levothyroxine administration in NAFLD patients who had euthyroidism or subclinical

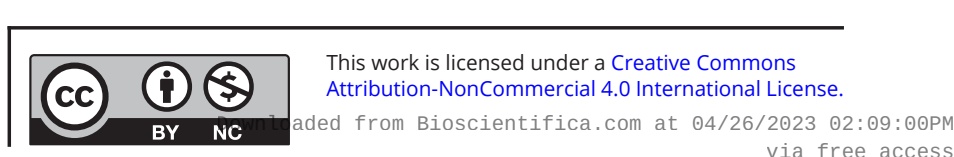


hypothyroidism $(93,94,95)$. Notably, thyroid hormones increase $\beta$-oxidation of fatty acids, which leads to a decrease in hepatic lipid content, at least in rodents (96). Moreover, thyroid hormones analogs decrease hepatic steatosis in different rodent models of NAFLD $(93,97)$. Also, TSH has been shown to increase hepatic triglyceride content through upregulation of SREBP-1c activity (91). Therefore, treating hypothyroidism would in theory reduce TSH and help improving NAFLD. Further studies are required to assess whether levothyroxine replacement in patients with concomitant hypothyroidism and NAFLD can have a positive impact on liver disease progression and outcomes.

\section{Male hypogonadism}

Male hypogonadism is a clinical syndrome defined by reduced testosterone secretion and/or spermatogenesis. Male hypogonadism can be caused by diseases of the testes (primary hypogonadism) or dysfunction of the hypothalamic-pituitary axis (secondary hypogonadism) (98). The clinical features of male hypogonadism depend on the time of onset and the severity of the androgen deficiency, as well as whether it involves an insufficiency of spermatogenesis and/or testosterone secretion. The diagnosis of hypogonadism is based on the presence of signs and symptoms compatible with testosterone deficiency and several reduced morning testosterone serum level measurements.

Studies in males have reported an association between low testosterone and increased visceral adipose tissue, insulin resistance, and dyslipidemia (99, 100). Accordingly, higher levels of testosterone are associated with reduced visceral abdominal adipose tissue (101). The association between low testosterone levels and NAFLD has been observed in several epidemiological studies, and a meta-analysis including 16 studies has confirmed this association between lower testosterone levels and NAFLD in men $(102,103,104)$.

Several mechanisms may play a role in the association between reduced testosterone levels and NAFLD, but they remain poorly described. An increase in abdominal adipose tissue with low testosterone levels may lead to hepatic steatosis and insulin resistance. Furthermore, low testosterone levels are associated with low-grade inflammation (99). Preclinical studies have shown that low levels or the absence of testosterone may cause hepatic steatosis through increased de novo lipogenesis via upregulation of hepatic SREBP-1. This upregulation of SREBP-2 and ACC-1 appears to be due to reduced
AMPKo-1 activity (105). Additionally, testosterone may activate SR-B1 scavenger receptor and stimulate hepatic lipase by hydrolysis of phospholipids and by hydrolysis of triglycerides, thereby leading to an enhancement of specific cholesterol uptake of HDL-C lipids by the liver as well as cholesterol efflux from peripheral cells (106). Therefore, low testosterone may favor uncontrolled hepatic lipid accumulation, thereby leading to the development of NAFLD.

In the preclinical setting, testosterone replacement has been associated with a beneficial impact on hepatic fat content in animal models such as castrated rats $(107,108)$. In humans, the benefit of testosterone administration in NAFLD is still a matter of debate, with conflicting results between randomized controlled trials. For example, one study found a significant reduction in hepatic fat content, while another study reported the absence of a reduction in hepatic fat $(109,110)$. In light of the limitations of the available studies, testosterone replacement cannot currently be considered as a treatment for NAFLD in men with low testosterone levels. Further studies are needed to obtain a better understanding of the impact of testosterone administration on the development and outcomes of NAFLD, and these studies should take into account several long-term safety aspects of testosterone replacement therapy, such as cardiovascular outcomes, as these remain a matter of debate (111).

\section{Growth hormone dysregulation}

\section{Growth hormone deficiency}

Liver is thought to be one of the key organ targets of growth hormone $(\mathrm{GH})$. $\mathrm{GH}$ exerts various physiological actions on glucose and lipid metabolism. GH stimulates glycogenolysis and gluconeogenesis, thereby inducing insulin resistance and promoting preferential release of free fatty acids from visceral adipose tissue, which in turn induces competition between fatty acids and glucose as a substrate, thereby reducing glucose metabolism (112). Due to its pronounced impact on lipid and glucose metabolism, the level of GH appears to be related to lipid accumulation in the liver. Deficiency or excess of $\mathrm{GH}$ appears to be associated with the risk of developing NAFLD.

Adult growth hormone deficiency (GHD) is clinically characterized by decreased muscle strength, increased visceral adipose tissue, dyslipidemia, and an increased risk of cardiovascular disease $(113,114)$. GHD in adults 
is usually caused by a pituitary adenoma or its treatment such as surgery. An association between GHD in adults and the development and severity of NAFLD has been reported in several observational studies. Thus, several studies have reported that IGF-1 and GH levels are reduced in patients with NAFLD $(115,116,117,118)$. There are several mechanisms that link GH deficiency and NAFLD, although the precise pathogenesis remains to be elucidated. Mice with liver-specific deletion of GH receptor exhibit severe hepatic steatosis, increased hepatic de novo lipogenesis, and insulin resistance (119, 120). Furthermore, the same mouse model exhibits other features of the metabolic syndrome such as lowgrade inflammation, increased reactive oxygen species production, and mitochondrial dysfunction.

Several clinical studies have reported potential beneficial effects of GH administration on liver enzyme levels and hepatic steatosis (121). GH replacement treatment in adults should only be provided in case of symptomatic and severe growth deficiency in order to decrease visceral adipose tissue, to improve lipid profile, and to reduce cardiovascular morbidity and mortality (122). Due to limited data to date in this regard, GH supplementation therapy should not be considered as a specific treatment for NAFLD patients with or without GH deficiency (123).

\section{Growth hormone excess}

Acromegaly is caused by the overproduction of GH and, consequently, IGF-1, and it is most often the result of somatotroph adenomas. Excess GH secretion results in deleterious effects on glucose metabolism and insulin signaling at hepatic and extra-hepatic sites by stimulation of gluconeogenesis and glycogenolysis. Excess GH causes an increase in lipolysis that leads to a high levels of free fatty acids, thereby further promoting the development of insulin resistance $(124,125)$.

Few studies to date have shown an association between acromegaly and NAFLD prevalence, and in particular the hepatic steatosis index (HSI). Interestingly, a reduction of GH and IGF-1 levels after treatment induction in acromegaly has been associated with a reduction of the HSI $(126,127)$. However, due to the relatively low prevalence of acromegaly, there is still limited data regarding its association with NAFLD and the impact of control of the disease with conventional treatments such as octreotide long-acting release on NAFLD progression or regression.

\section{Glucocorticoid excess}

Excessive levels of glucocorticoids (GCs) have been linked to the risk of developing NAFLD, as GCs may modulate several key pathways involved in lipid and carbohydrate metabolism (128). Excessive levels of endogenous GCs, as occurs in Cushing's syndrome, have been associated with a prevalence of $20 \%$ of NAFLD in a study assessing hepatic fat content with CT in individuals with active Cushing's syndrome (129). In accordance with this, the exogenous GC hydrocortisone has been shown to be associated, in a dose-dependent manner, with an increased risk of NAFLD independently of the BMI or waist circumference (130). Currently available data are still not in agreement regarding the presence or not of hypercortisolism in patients with metabolic syndrome and NAFLD and the potential increased risk of the occurrence of a metabolic disturbance such as type 2 diabetes or insulin resistance in the presence of elevated levels of cortisol (131, 132, 133).

Excess GCs can mediate hepatic fat accumulation through several mechanisms, including the stimulation of de novo hepatic lipogenesis, increased gluconeogenesis, the stimulation of food intake, inhibition of hepatic $\beta$-oxidation, and enhancement of lipolysis of adipose tissue and free fatty acids uptake by the liver (128). The enzyme 11ß-hydroxysteroid dehydrogenase type 1 (11 $\beta$-HSD1), which converts inactive cortisone to active cortisol, appears to play a potentially important role in excess GC-mediated development of NAFLD and insulin resistance. This enzyme is upregulated in the visceral adipose tissue of obese individuals, thereby leading to increased hepatic exposure of cortisol by the splanchnic venous system (134). In keeping with this, mice with adipose tissue-specific $\mathrm{KO}$ of $11 \beta$-HSD1 are protected against the development of the metabolic syndrome and, conversely, mice that overexpress 11ß-HSD1 in adipose tissue are prone to developing NAFLD and insulin resistance (135). 11ß-HSD1 inhibitors have been shown to have a beneficial effect on metabolic syndrome, and their use can, therefore, be considered as a potential future therapy for NAFLD $(136,137)$.

$5 \alpha$-reductase is another enzyme involved in GC metabolism. Notably, it has been suggested that $5 \alpha$-reductase activation might act as a protective mechanism preventing progression of metabolic disturbances in the liver through increased local GC clearance (138). Also, mice knock-out for $5 \alpha$-reductase are predisposed to insulin resistance and NAFLD (83). Finally, $5 \alpha$-reductase inhibition through the use of dutasteride

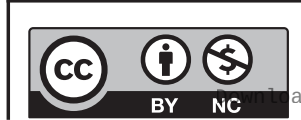

This work is licensed under a Creative Commons Attribution-NonCommercial 4.0 International License. ded from Bioscientifica.com at 04/26/2023 02:09:00PM 
has been shown to promote hepatic fat accumulation in humans (139).

Altogether, excess GCs levels appear to play an important role in the development of insulin resistance and NAFLD, although clinical applications to potentially counteract GCs action remain to be elucidated.

\section{Miscellaneous}

Vitamin D deficiency has been associated in various observational data with the development and severity of NAFLD in subjects with normal aminotransferases (AST/ ALT) levels $(140,141)$. In addition, NAFLD patients have an additional risk of low vitamin D of approximately $25 \%$ compared with subjects without NAFLD (142). However, the association between the risk of future new-onset insulin resistance and low vitamin D remains unclear $(143,144)$.

Mechanistically, vitamin D acts through the vitamin D receptor (VDR) present in hepatocytes. Vitamin D has been shown to enhance insulin sensitivity in vitro through upregulation of GLUT4 and modification of free fatty acids metabolism (145). Preclinical studies suggest potential anti-inflammatory, antiproliferative, and antifibrotic effects of vitamin D administration on the liver in vivo $(146,147)$. Small-scale randomized controlled trials have shown that vitamin D supplementation improves the metabolic syndrome $(148,149,150)$.

Several observational case-control or cross-sectional studies have assessed the association between NAFLD and bone mineral density (BMD). The findings to date of studies in this regard remain conflicting, with some studies showing a significant association between NAFLD and low BMD, while other studies have reported a significant association between NAFLD and increased BMD, and, lastly, some studies have observed no association (151, $152,153,154)$. Larger-scale prospective and mechanistic studies are warranted to better elucidate the potential link between bone demineralization and NAFLD, with investigation of gender differences and any specific segment of the skeleton that can be affected.

Primary aldosteronism (PA) is the most frequent cause of secondary hypertension, accounting for approximately $10 \%$ of all cases (155). PA can not only cause hypertension but also insulin resistance and dyslipidemia (156). Activation of the mineralocorticoid receptor by aldosterone leads to impaired insulin sensitivity in skeletal muscle and adipocytes by stimulation of inflammatory and oxidative stress metabolic pathways $(157,158)$. PA has been reported to increase the risk of metabolic syndrome and NAFLD $(159,160,161)$. Thus, there may be merit in screening patients with PA for NAFLD. The impact of therapeutic or surgical treatments of PA on the development and outcome of NAFLD remain to be determined.

Prolactin is a pituitary-derived hormone with potent enhancing effects on reproduction and lactation. Since the receptor of prolactin is also present in liver, it may play a role in hepatic metabolic regulation. A negative correlation between prolactin plasma levels and body weight, insulin resistance, and NAFLD development has been observed in observational studies $(162,163)$. The prolactin receptor is down-regulated in obese subjects with NAFLD, and in vitro experiments indicate that prolactin, via its hepatic receptor, improves hepatic steatosis through a reduction of fatty acid translocase (FAT)/CD36, which is a major transporter for hepatic uptake of free fatty acids (162). Prolactin and its hepatic receptor may, therefore, represent an attractive approach to counteract the development of NAFLD.

\section{Summary and conclusion}

NAFLD is the most common chronic liver disease in Western countries, with NASH being a more progressive subtype notably characterized by inflammation and hepatocyte injury, with or without fibrosis. The latter is the only histologic feature associated with long-term outcomes of patients with NAFLD. NAFLD is intimately entangled with various endocrine diseases, sharing the keystone pathophysiological mechanism of insulin resistance. However, our understanding of the pathophysiology of NAFLD in different endocrinopathies is far from being understood and therefore limits our capacity to more specifically treat NAFLD in this context. Moreover, the natural course of NAFLD secondary to endocrine disorders compared to the course of 'primary' NAFLD is unknown. Therefore, in the coming years, it will be of importance to better understand the interrelationships between endocrine diseases and NAFLD in order to better target treatments.

Declaration of interest

The authors declare that there is no conflict of interest that could be perceived as prejudicing the impartiality of this review.

\section{Funding}

This work did not receive any specific grant from any funding agency in the public, commercial or not-for-profit sector.

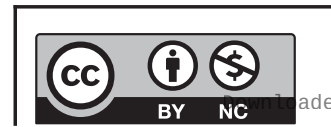

This work is licensed under a Creative Commons Attribution-NonCommercial 4.0 International License. ded from Bioscientifica.com at 04/26/2023 02:09:0๑PM via free access 


\section{Author contribution statement}

K G and F R J wrote the paper and contributed equally.

\section{References}

1 Asrih M \& Jornayvaz FR. Inflammation as a potential link between nonalcoholic fatty liver disease and insulin resistance. Journal of Endocrinology 2013218 R25-R36. (https://doi.org/10.1530/JOE-130201)

2 Asrih M \& Jornayvaz FR. Diets and nonalcoholic fatty liver disease: the good and the bad. Clinical Nutrition 201433 186-190. (https:// doi.org/10.1016/j.clnu.2013.11.003)

3 Asrih M \& Jornayvaz FR. Metabolic syndrome and nonalcoholic fatty liver disease: is insulin resistance the link? Molecular \& Cellular Endocrinology 2015418 55-65. (https://doi.org/10.1016/j. mce.2015.02.018)

4 Gariani K, Philippe J \& Jornayvaz FR. Non-alcoholic fatty liver disease and insulin resistance: from bench to bedside. Diabetes \& Metabolism 201339 16-26. (https://doi.org/10.1016/j.diabet.2012.11.002)

5 Angulo P, Kleiner DE, Dam-Larsen S, Adams LA, Bjornsson ES, Charatcharoenwitthaya P, Mills PR, Keach JC, Lafferty HD, Stahler A, et al. Liver fibrosis, but no other histologic features, is associated with long-term outcomes of patients with nonalcoholic fatty liver disease. Gastroenterology 2015 149-397 e310. (https://doi.org/10.1053/j. gastro.2015.04.043)

6 Tang JT \& Mao YM. Development of new drugs for the treatment of nonalcoholic steatohepatitis. Journal of Digestive Diseases 202021 3-11. (https://doi.org/10.1111/1751-2980.12830)

7 Lonardo A, Mantovani A, Lugari S \& Targher G. NAFLD in some common endocrine diseases: prevalence, pathophysiology, and principles of diagnosis and management. International Journal of Molecular Sciences 2019 20. (https://doi.org/10.3390/ijms20112841)

8 Marino L \& Jornayvaz FR. Endocrine causes of nonalcoholic fatty liver disease. World Journal of Gastroenterology 201521 11053-11076. (https://doi.org/10.3748/wjg.v21.i39.11053)

9 Wang T, Yang W, Karakas S \& Sarkar S. NASH in nondiabetic endocrine disorders. Metabolic Syndrome \& Related Disorders 201816 315-320. (https://doi.org/10.1089/met.2018.0044)

10 Chalasani N, Younossi Z, Lavine JE, Charlton M, Cusi K, Rinella M, Harrison SA, Brunt EM \& Sanyal AJ. The diagnosis and management of nonalcoholic fatty liver disease: practice guidance from the American Association for the study of liver diseases. Hepatology 2018 67 328-357. (https://doi.org/10.1002/hep.29367)

11 Younossi ZM, Stepanova M, Ong J, Trimble G, AlQahtani S, Younossi I, Ahmed A, Racila A \& Henry L. Nonalcoholic steatohepatitis is the most rapidly increasing indication for liver transplantation in the United States. Clinical Gastroenterology and Hepatology 2020 [epub]. (https://doi.org/10.1016/j.cgh.2020.05.064)

12 Bellentani S \& Marino M. Epidemiology and natural history of non-alcoholic fatty liver disease (NAFLD). Annals of Hepatology 2009 8(Supplement 1) S4-S8. (https://doi.org/10.1016/S16652681(19)31820-4).

13 Younossi Z, Tacke F, Arrese M, Chander Sharma B, Mostafa I, Bugianesi E, Wai-Sun V, Yilmaz Y, George J, Fan J, et al. Global perspectives on nonalcoholic fatty liver disease and nonalcoholic steatohepatitis. Hepatology 201969 2672-2682. (https://doi. org/10.1002/hep.30251)

14 Younossi ZM, Golabi P, de Avila L, Paik JM, Srishord M, Fukui N, Qiu Y, Burns L, Afendy A \& Nader F. The global epidemiology of NAFLD and NASH in patients with type 2 diabetes: a systematic review and meta-analysis. Journal of Hepatology 201971 793-801. (https://doi.org/10.1016/j.jhep.2019.06.021)

15 Sheka AC, Adeyi O, Thompson J, Hameed B, Crawford PA \& Ikramuddin S. Nonalcoholic steatohepatitis: a review. JAMA 2020 323 1175-1183. (https://doi.org/10.1001/jama.2020.2298)
16 Cotter TG \& Rinella M. Nonalcoholic fatty liver Disease 2020: the state of the disease. Gastroenterology 2020158 1851-1864. (https:// doi.org/10.1053/j.gastro.2020.01.052).

17 McCullough AJ. Pathophysiology of nonalcoholic steatohepatitis. Journal of Clinical Gastroenterology $2006 \mathbf{4 0}$ (Supplement 1) S17-S29.

18 Serfaty L \& Lemoine M. Definition and natural history of metabolic steatosis: clinical aspects of NAFLD, NASH and cirrhosis. Diabetes \& Metabolism 200834 634-637. (https://doi.org/10.1016/S12623636(08)74597-X)

19 Alberti KG, Eckel RH, Grundy SM, Zimmet PZ, Cleeman JI, Donato KA, Fruchart JC, James WP, Loria CM, Smith SC, Jr, et al. Harmonizing the metabolic syndrome: a joint interim statement of the International Diabetes Federation Task Force on epidemiology and prevention; National Heart, Lung, and Blood Institute; American Heart Association; World Heart Federation; International Atherosclerosis Society; and International Association for the Study of Obesity. Circulation 2009120 1640-1645. (https://doi. org/10.1161/CIRCULATIONAHA.109.192644)

20 Jornayvaz FR, Samuel VT \& Shulman GI. The role of muscle insulin resistance in the pathogenesis of atherogenic dyslipidemia and nonalcoholic fatty liver disease associated with the metabolic syndrome. Annual Review of Nutrition 201030 273-290. (https://doi. org/10.1146/annurev.nutr.012809.104726)

21 Hernaez R, Lazo M, Bonekamp S, Kamel I, Brancati FL, Guallar E \& Clark JM. Diagnostic accuracy and reliability of ultrasonography for the detection of fatty liver: a meta-analysis. Hepatology 201154 1082-1090. (https://doi.org/10.1002/hep.24452)

22 Goossens N, Bellentani S, Cerny A, Dufour JF, Jornayvaz FR, Mertens J, Moriggia A, Muellhaupt B, Negro F, Razavi H, et al. Nonalcoholic fatty liver disease burden - Switzerland 2018-2030. Swiss Medical Weekly 2019149 w20152. (https://doi.org/10.4414/ smw.2019.20152)

23 Goossens N \& Jornayvaz FR. Translational aspects of diet and non-alcoholic fatty liver disease. Nutrients 2017 9. (https://doi. org/10.3390/nu9101077)

24 Kosinski C \& Jornayvaz FR. Effects of ketogenic diets on cardiovascular risk factors: evidence from animal and human studies. Nutrients 20179 517-532. (https://doi.org/10.3390/ nu9050517)

25 Somm E \& Jornayvaz FR. Fibroblast growth factor 15/19: From basic functions to therapeutic perspectives. Endocrine Reviews 201839 960-989. (https://doi.org/10.1210/er.2018-00134)

26 Montandon SA, Somm E, Loizides-Mangold U, de Vito C, Dibner C \& Jornayvaz FR. Multi-technique comparison of atherogenic and MCD NASH models highlights changes in sphingolipid metabolism. Scientific Reports 20199 16810. (https://doi.org/10.1038/s41598-01953346-4)

27 Parthasarathy G, Revelo X \& Malhi H. Pathogenesis of nonalcoholic steatohepatitis: an overview. Hepatology Communications 20204 478-492. (https://doi.org/10.1002/hep4.1479)

28 Friedman SL, Neuschwander-Tetri BA, Rinella M \& Sanyal AJ. Mechanisms of NAFLD development and therapeutic strategies. Nature Medicine 201824 908-922. (https://doi.org/10.1038/s41591018-0104-9)

29 Buzzetti E, Pinzani M \& Tsochatzis EA. The multiple-hit pathogenesis of non-alcoholic fatty liver disease (NAFLD). Metabolism: Clinical and Experimental 201665 1038-1048. (https://doi.org/10.1016/j. metabol.2015.12.012)

30 Bugianesi E, Moscatiello S, Ciaravella MF \& Marchesini G. Insulin resistance in nonalcoholic fatty liver disease. Current Pharmaceutical Design 201016 1941-1951. (https://doi. org/10.2174/138161210791208875)

31 Guilherme A, Virbasius JV, Puri V \& Czech MP. Adipocyte dysfunctions linking obesity to insulin resistance and type 2 diabetes. Nature Reviews. Molecular Cell Biology 20089 367-377. (https://doi.org/10.1038/nrm2391)

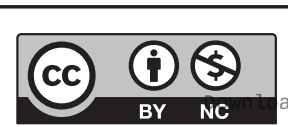

This work is licensed under a Creative Commons Attribution-NonCommercial 4.0 International License. ded from Bioscientifica.com at 04/26/2023 02:09:00PM 
32 Mansouri A, Gattolliat CH \& Asselah T. Mitochondrial dysfunction and signaling in chronic liver diseases. Gastroenterology 2018155 629-647. (https://doi.org/10.1053/j.gastro.2018.06.083)

33 Kirpich IA, Marsano LS \& McClain CJ. Gut-liver axis, nutrition, and non-alcoholic fatty liver disease. Clinical Biochemistry $2015 \mathbf{4 8}$ 923-930. (https://doi.org/10.1016/j.clinbiochem.2015.06.023)

34 Jornayvaz FR \& Shulman GI. Diacylglycerol activation of protein kinase cepsilon and hepatic insulin resistance. Cell Metabolism 2012 15 574-584. (https://doi.org/10.1016/j.cmet.2012.03.005)

35 Birkenfeld AL, Lee HY, Guebre-Egziabher F, Alves TC, Jurczak MJ, Jornayvaz FR, Zhang D, Hsiao JJ, Martin-Montalvo A, FischerRosinsky A, et al. Deletion of the mammalian INDY homolog mimics aspects of dietary restriction and protects against adiposity and insulin resistance in mice. Cell Metabolism 201114 184-195. (https:// doi.org/10.1016/j.cmet.2011.06.009)

36 Choi CS, Savage DB, Abu-Elheiga L, Liu ZX, Kim S, Kulkarni A, Distefano A, Hwang YJ, Reznick RM, Codella R, et al. Continuous fat oxidation in acetyl-CoA carboxylase 2 knockout mice increases total energy expenditure, reduces fat mass, and improves insulin sensitivity. Proceedings of the National Academy of Sciences of the United States of America 2007104 16480-16485. (https://doi.org/10.1073/ pnas.0706794104)

37 Erion DM, Ignatova ID, Yonemitsu S, Nagai Y, Chatterjee P, Weismann D, Hsiao JJ, Zhang D, Iwasaki T, Stark R, et al. Prevention of hepatic steatosis and hepatic insulin resistance by knockdown of cAMP response element-binding protein. Cell Metabolism 200910 499-506. (https://doi.org/10.1016/j.cmet.2009.10.007)

38 Jornayvaz FR, Birkenfeld AL, Jurczak MJ, Kanda S, Guigni BA, Jiang DC, Zhang D, Lee HY, Samuel VT \& Shulman GI. Hepatic insulin resistance in mice with hepatic overexpression of diacylglycerol acyltransferase 2. Proceedings of the National Academy of Sciences of the United States of America 2011108 5748-5752. (https:// doi.org/10.1073/pnas.1103451108)

39 Jornayvaz FR, Jurczak MJ, Lee HY, Birkenfeld AL, Frederick DW, Zhang D, Zhang XM, Samuel VT \& Shulman GI. A high-fat, ketogenic diet causes hepatic insulin resistance in mice, despite increasing energy expenditure and preventing weight gain. American Journal of Physiology. Endocrinology \& Metabolism 2010299 E808-E815. (https://doi.org/10.1152/ajpendo.00361.2010)

40 Jornayvaz FR, Lee HY, Jurczak MJ, Alves TC, Guebre-Egziabher F, Guigni BA, Zhang D, Samuel VT, Silva JE \& Shulman GI. Thyroid hormone receptor-alpha gene knockout mice are protected from dietinduced hepatic insulin resistance. Endocrinology 2012153 583-591. (https://doi.org/10.1210/en.2011-1793)

41 Lee HY, Birkenfeld AL, Jornayvaz FR, Jurczak MJ, Kanda S, Popov V, Frederick DW, Zhang D, Guigni B, Bharadwaj KG, et al. Apolipoprotein CIII overexpressing mice are predisposed to dietinduced hepatic steatosis and hepatic insulin resistance. Hepatology 201154 1650-1660. (https://doi.org/10.1002/hep.24571)

42 Nagai Y, Yonemitsu S, Erion DM, Iwasaki T, Stark R, Weismann D, Dong J, Zhang D, Jurczak MJ, Loffler MG, et al. The role of peroxisome proliferator-activated receptor gamma coactivator-1 beta in the pathogenesis of fructose-induced insulin resistance. Cell Metabolism 20099 252-264. (https://doi.org/10.1016/j.cmet.2009.01.011)

43 Neschen S, Morino K, Hammond LE, Zhang D, Liu ZX, Romanelli AJ, Cline GW, Pongratz RL, Zhang XM, Choi CS, et al. Prevention of hepatic steatosis and hepatic insulin resistance in mitochondrial acyl-CoA:glycerol-sn-3-phosphate acyltransferase 1 knockout mice. Cell Metabolism 20052 55-65. (https://doi.org/10.1016/j. cmet.2005.06.006)

44 Savage DB, Choi CS, Samuel VT, Liu ZX, Zhang D, Wang A, Zhang XM, Cline GW, Yu XX, Geisler JG, et al. Reversal of dietinduced hepatic steatosis and hepatic insulin resistance by antisense oligonucleotide inhibitors of acetyl-CoA carboxylases 1 and 2. Journal of Clinical Investigation 2006116 817-824. (https://doi.org/10.1172/ JCI27300)
45 Zhang D, Liu ZX, Choi CS, Tian L, Kibbey R, Dong J, Cline GW, Wood PA \& Shulman GI. Mitochondrial dysfunction due to longchain acyl-CoA dehydrogenase deficiency causes hepatic steatosis and hepatic insulin resistance. Proceedings of the National Academy of Sciences of the United States of America $2007 \mathbf{1 0 4} 17075-17080$. (https://doi.org/10.1073/pnas.0707060104)

46 Asrih M, Altirriba J, Rohner-Jeanrenaud F \& Jornayvaz FR. Ketogenic diet impairs FGF21 signaling and promotes differential inflammatory responses in the liver and white adipose tissue. PLOS ONE 201510 e0126364. (https://doi.org/10.1371/journal. pone.0126364)

47 Camporez JP, Asrih M, Zhang D, Kahn M, Samuel VT, Jurczak MJ \& Jornayvaz FR. Hepatic insulin resistance and increased hepatic glucose production in mice lacking FGF21. Journal of Endocrinology 2015226 207-217. (https://doi.org/10.1530/JOE-15-0136)

48 Kumashiro N, Erion DM, Zhang D, Kahn M, Beddow SA, Chu X, Still CD, Gerhard GS, Han X, Dziura J, et al. Cellular mechanism of insulin resistance in nonalcoholic fatty liver disease. Proceedings of the National Academy of Sciences of the United States of America $2011 \mathbf{1 0 8}$ 16381-16385. (https://doi.org/10.1073/pnas.1113359108)

49 Camporez JP, Kanda S, Petersen MC, Jornayvaz FR, Samuel VT, Bhanot S, Petersen KF, Jurczak MJ \& Shulman GI. ApoA5 knockdown improves whole-body insulin sensitivity in high-fat-fed mice by reducing ectopic lipid content. Journal of Lipid Research 201556 526-536. (https://doi.org/10.1194/jlr.M054080)

50 Birkenfeld AL, Lee HY, Majumdar S, Jurczak MJ, Camporez JP, Jornayvaz FR, Frederick DW, Guigni B, Kahn M, Zhang D, et al. Influence of the hepatic eukaryotic initiation factor 2alpha (eIF2alpha) endoplasmic reticulum (ER) stress response pathway on insulin-mediated ER stress and hepatic and peripheral glucose metabolism. Journal of Biological Chemistry $201128636163-36170$. (https://doi.org/10.1074/jbc.M111.228817)

51 Jurczak MJ, Lee AH, Jornayvaz FR, Lee HY, Birkenfeld AL, Guigni BA, Kahn M, Samuel VT, Glimcher LH \& Shulman GI. Dissociation of inositol-requiring enzyme (IRE1alpha)-mediated c-Jun N-terminal kinase activation from hepatic insulin resistance in conditional X-box-binding protein-1 (XBP1) knock-out mice. Journal of Biological Chemistry 2012287 2558-2567. (https://doi.org/10.1074/jbc. M111.316760)

52 Cantley JL, Yoshimura T, Camporez JP, Zhang D, Jornayvaz FR, Kumashiro N, Guebre-Egziabher F, Jurczak MJ, Kahn M, Guigni BA, et al. CGI-58 knockdown sequesters diacylglycerols in lipid droplets/ER-preventing diacylglycerol-mediated hepatic insulin resistance. Proceedings of the National Academy of Sciences of the United States of America 2013110 1869-1874. (https://doi.org/10.1073/ pnas.1219456110).

53 Camporez JP, Jornayvaz FR, Lee HY, Kanda S, Guigni BA, Kahn M, Samuel VT, Carvalho CR, Petersen KF, Jurczak MJ, et al. Cellular mechanism by which estradiol protects female ovariectomized mice from high-fat diet-induced hepatic and muscle insulin resistance. Endocrinology 2013154 1021-1028. (https://doi.org/10.1210/ en.2012-1989).

54 Watt MJ, Miotto PM, De Nardo W \& Montgomery MK. The liver as an endocrine organ-linking NAFLD and insulin resistance. Endocrine Reviews 201940 1367-1393. (https://doi.org/10.1210/er.201900034).

55 Fon Tacer K, Bookout AL, Ding X, Kurosu H, John GB, Wang L, Goetz R, Mohammadi M, Kuro-o M, Mangelsdorf DJ, et al. Research resource: comprehensive expression atlas of the fibroblast growth factor system in adult mouse. Molecular Endocrinology 201024 2050-2064. '(https://doi.org/10.1210/me.2010-0142).

56 Inagaki T, Dutchak P, Zhao G, Ding X, Gautron L, Parameswara V, Li Y, Goetz R, Mohammadi M, Esser V, et al. Endocrine regulation of the fasting response by PPARalpha-mediated induction of fibroblast growth factor 21. Cell Metabolism 20075 415-425. (https://doi. org/10.1016/j.cmet.2007.05.003).

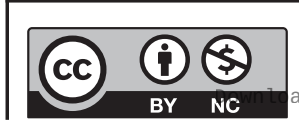


57 Woo YC, Xu A, Wang Y \& Lam KS. Fibroblast growth factor 21 as an emerging metabolic regulator: clinical perspectives. Clinical Endocrinology 201378 489-496. (https://doi.org/10.1111/cen.12095).

58 Li H, Fang Q, Gao F, Fan J, Zhou J, Wang X, Zhang H, Pan X, Bao Y, Xiang $\mathrm{K}$, et al. Fibroblast growth factor 21 levels are increased in nonalcoholic fatty liver disease patients and are correlated with hepatic triglyceride. Journal of Hepatology 201053 934-940. (https:// doi.org/10.1016/j.jhep.2010.05.018).

59 Morris-Stiff G \& Feldstein AE. Fibroblast growth factor 21 as a biomarker for NAFLD: integrating pathobiology into clinical practice. Journal of Hepatology 201053 795-796. (https://doi.org/10.1016/j. jhep.2010.07.003).

60 Dushay J, Chui PC, Gopalakrishnan GS, Varela-Rey M, Crawley M, Fisher FM, Badman MK, Martinez-Chantar ML \& Maratos-Flier E. Increased fibroblast growth factor 21 in obesity and nonalcoholic fatty liver disease. Gastroenterology 2010139 456-463. (https://doi. org/10.1053/j.gastro.2010.04.054).

61 Camporez JP, Jornayvaz FR, Petersen MC, Pesta D, Guigni BA, Serr J, Zhang D, Kahn M, Samuel VT, Jurczak MJ, et al. Cellular mechanisms by which FGF21 improves insulin sensitivity in male mice. Endocrinology 2013154 3099-3109. (https://doi.org/10.1210/ en.2013-1191)

62 Coskun T, Bina HA, Schneider MA, Dunbar JD, Hu CC, Chen Y, Moller DE \& Kharitonenkov A. Fibroblast growth factor 21 corrects obesity in mice. Endocrinology 2008149 6018-6027. (https://doi. org/10.1210/en.2008-0816).

63 Kharitonenkov A, Shiyanova TL, Koester A, Ford AM, Micanovic R, Galbreath EJ, Sandusky GE, Hammond LJ, Moyers JS, Owens RA, et al. FGF-21 as a novel metabolic regulator. Journal of Clinical Investigation 2005115 1627-1635. (https://doi.org/10.1172/JCI23606).

64 Kharitonenkov A, Wroblewski VJ, Koester A, Chen YF, Clutinger CK, Tigno XT, Hansen BC, Shanafelt AB \& Etgen GJ. The metabolic state of diabetic monkeys is regulated by fibroblast growth factor- 21 . Endocrinology 2007148 774-781. (https://doi.org/10.1210/en.20061168).

65 Veniant MM, Komorowski R, Chen P, Stanislaus S, Winters K, Hager T, Zhou L, Wada R, Hecht R \& Xu J. Long-acting FGF21 has enhanced efficacy in diet-induced obese mice and in obese rhesus monkeys. Endocrinology 2012153 4192-4203. (https://doi. org/10.1210/en.2012-1211).

66 Xu J, Lloyd DJ, Hale C, Stanislaus S, Chen M, Sivits G, Vonderfecht S, Hecht R, Li YS, Lindberg RA, et al. Fibroblast growth factor 21 reverses hepatic steatosis, increases energy expenditure, and improves insulin sensitivity in diet-induced obese mice. Diabetes 200958 250-259. (https://doi.org/10.2337/db08-0392).

67 Gariani K, Drifte G, Dunn-Siegrist I, Pugin J \& Jornayvaz FR. Increased FGF21 plasma levels in humans with sepsis and SIRS. Endocrine Connections 20132 146-153. (https://doi.org/10.1530/ EC-13-0040)

68 Gaich G, Chien JY, Fu H, Glass LC, Deeg MA, Holland WL, Kharitonenkov A, Bumol T, Schilske HK \& Moller DE. The effects of LY2405319, an FGF21 analog, in obese human subjects with type 2 diabetes. Cell Metabolism 201318 333-340. (https://doi. org/10.1016/j.cmet.2013.08.005).

69 Tucker B, Li H, Long X, Rye KA \& Ong KL. Fibroblast growth factor 21 in non-alcoholic fatty liver disease. Metabolism: Clinical and Experimental 2019101 153994. (https://doi.org/10.1016/j. metabol.2019.153994).

70 Legro RS, Arslanian SA, Ehrmann DA, Hoeger KM, Murad MH, Pasquali R, Welt CK \& Endocrine Society. Diagnosis and treatment of polycystic ovary syndrome: an Endocrine Society clinical practice guideline. Journal of Clinical Endocrinology \& Metabolism 201398 4565-4592. (https://doi.org/10.1210/jc.2013-2350).

71 Welt CK \& Duran JM. Genetics of polycystic ovary syndrome. Seminars in Reproductive Medicine 201432 177-182. (https://doi. org/10.1055/s-0034-1371089).
72 Kauffman RP, Baker TE, Baker V, Kauffman MM \& Castracane VD. Endocrine factors associated with non-alcoholic fatty liver disease in women with polycystic ovary syndrome: do androgens play a role? Gynecological Endocrinology 201026 39-46. (https://doi. org/10.3109/09513590903184084).

$73 \mathrm{Wu}$ J, Yao XY, Shi RX, Liu SF \& Wang XY. A potential link between polycystic ovary syndrome and non-alcoholic fatty liver disease: an update meta-analysis. Reproductive Health 201815 77. (https://doi. org/10.1186/s12978-018-0519-2).

74 Kumarendran B, O'Reilly MW, Manolopoulos KN, Toulis KA, Gokhale KM, Sitch AJ, Wijeyaratne CN, Coomarasamy A, Arlt W $\&$ Nirantharakumar K. Polycystic ovary syndrome, androgen excess, and the risk of nonalcoholic fatty liver disease in women: a longitudinal study based on a United Kingdom primary care database. PLOS Medicine 201815 e1002542. (https://doi.org/10.1371/ journal.pmed.1002542).

75 Targher G, Rossini M \& Lonardo A. Evidence that non-alcoholic fatty liver disease and polycystic ovary syndrome are associated by necessity rather than chance: a novel hepato-ovarian axis? Endocrine 201651 211-221. (https://doi.org/10.1007/s12020-015-0640-8).

76 Setji TL, Holland ND, Sanders LL, Pereira KC, Diehl AM \& Brown AJ. Nonalcoholic steatohepatitis and nonalcoholic Fatty liver disease in young women with polycystic ovary syndrome. Journal of Clinical Endocrinology \& Metabolism 200691 1741-1747. (https://doi. org/10.1210/jc.2005-2774).

77 Brzozowska MM, Ostapowicz G \& Weltman MD. An association between non-alcoholic fatty liver disease and polycystic ovarian syndrome. Journal of Gastroenterology \& Hepatology 200924 243-247. (https://doi.org/10.1111/j.1440-1746.2008.05740.x).

78 Barbieri RL, Makris A, Randall RW, Daniels G, Kistner RW \& Ryan KJ. Insulin stimulates androgen accumulation in incubations of ovarian stroma obtained from women with hyperandrogenism. Journal of Clinical Endocrinology \& Metabolism 198662 904-910. (https://doi. org/10.1210/jcem-62-5-904).

79 Randeva HS, Tan BK, Weickert MO, Lois K, Nestler JE, Sattar N \& Lehnert H. Cardiometabolic aspects of the polycystic ovary syndrome. Endocrine Reviews 201233 812-841. (https://doi. org/10.1210/er.2012-1003).

80 Rocha ALL, Faria LC, Guimaraes TCM, Moreira GV, Candido AL, Couto CA \& Reis FM. Non-alcoholic fatty liver disease in women with polycystic ovary syndrome: systematic review and metaanalysis. Journal of Endocrinological Investigation 201740 1279-1288. (https://doi.org/10.1007/s40618-017-0708-9).

81 O'Reilly MW, Kempegowda P, Walsh M, Taylor AE, Manolopoulos KN, Allwood JW, Semple RK, Hebenstreit D, Dunn WB, Tomlinson JW, et al. AKR1C3-mediated adipose androgen generation drives lipotoxicity in women with polycystic ovary syndrome. Journal of Clinical Endocrinology \& Metabolism 2017102 3327-3339. (https://doi.org/10.1210/jc.2017-00947).

82 Anjani K, Lhomme M, Sokolovska N, Poitou C, Aron-Wisnewsky J, Bouillot JL, Lesnik P, Bedossa P, Kontush A, Clement K, et al. Circulating phospholipid profiling identifies portal contribution to NASH signature in obesity. Journal of Hepatology 201562 905-912. (https://doi.org/10.1016/j.jhep.2014.11.002).

83 Livingstone DE, Barat P, Di Rollo EM, Rees GA, Weldin BA, RogZielinska EA, MacFarlane DP, Walker BR \& Andrew R. 5Alphareductase type 1 deficiency or inhibition predisposes to insulin resistance, hepatic steatosis, and liver fibrosis in rodents. Diabetes 201564 447-458. (https://doi.org/10.2337/db14-0249).

84 Chaker L, Bianco AC, Jonklaas J \& Peeters RP. Hypothyroidism. Lancet 2017390 1550-1562. (https://doi.org/10.1016/S01406736(17)30703-1).

85 Lonardo A, Ballestri S, Mantovani A, Nascimbeni F, Lugari S \& Targher G. Pathogenesis of hypothyroidism-induced NAFLD: evidence for a distinct disease entity? Digestive and Liver Disease 2019 51 462-470. (https://doi.org/10.1016/j.dld.2018.12.014).

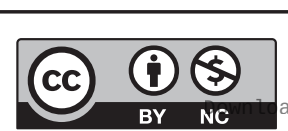

This work is licensed under a Creative Commons Attribution-NonCommercial 4.0 International License. ded from Bioscientifica.com at 04/26/2023 ०2:09:००PM 
86 Lonardo A, Nascimbeni F, Mantovani A \& Targher G. Hypertension, diabetes, atherosclerosis and NASH: cause or consequence? Journal of Hepatology 201868 335-352. (https://doi.org/10.1016/j. jhep.2017.09.021)

87 Eshraghian A \& Hamidian Jahromi A. Non-alcoholic fatty liver disease and thyroid dysfunction: a systematic review. World Journal of Gastroenterology 201420 8102-8109. (https://doi.org/10.3748/wjg. v20.i25.8102)

88 Chung GE, Kim D, Kim W, Yim JY, Park MJ, Kim YJ, Yoon JH \& Lee HS. Non-alcoholic fatty liver disease across the spectrum of hypothyroidism. Journal of Hepatology 201257 150-156. (https://doi. org/10.1016/j.jhep.2012.02.027).

89 Sinha RA, Singh BK \& Yen PM. Direct effects of thyroid hormones on hepatic lipid metabolism. Nature Reviews. Endocrinology 201814 259-269. (https://doi.org/10.1038/nrendo.2018.10).

90 Lugari S, Mantovani A, Nascimbeni F \& Lonardo A. Hypothyroidism and nonalcoholic fatty liver disease - a chance association? Hormone Molecular Biology \& Clinical Investigation 2018 41. (https://doi. org/10.1515/hmbci-2018-0047).

91 Yan F, Wang Q, Lu M, Chen W, Song Y, Jing F, Guan Y, Wang L, Lin Y, Bo T, et al. Thyrotropin increases hepatic triglyceride content through upregulation of SREBP-1c activity. Journal of Hepatology 2014 61 1358-1364. (https://doi.org/10.1016/j.jhep.2014.06.037).

$92 \mathrm{Xu} \mathrm{L}, \mathrm{Ma} \mathrm{H}$, Miao M \& Li Y. Impact of subclinical hypothyroidism on the development of non-alcoholic fatty liver disease: a prospective case-control study. Journal of Hepatology 201257 1153-1154. (https:// doi.org/10.1016/j.jhep.2012.05.025).

93 Bruinstroop E, Dalan R, Cao Y, Bee YM, Chandran K, Cho LW, Soh SB, Teo EK, Toh SA, Leow MKS, et al. Low-dose levothyroxine reduces intrahepatic lipid content in patients With type 2 diabetes mellitus and NAFLD. Journal of Clinical Endocrinology \& Metabolism 2018103 2698-2706. (https://doi.org/10.1210/jc.2018-00475).

94 Liu L, Yu Y, Zhao M, Zheng D, Zhang X, Guan Q, Xu C, Gao L, Zhao J \& Zhang H. Benefits of levothyroxine replacement therapy on nonalcoholic fatty liver disease in subclinical hypothyroidism patients. International Journal of Endocrinology 201720175753039. (https://doi.org/10.1155/2017/5753039).

95 Harrison S, Moussa S, Bashir M, Alkhouri N, Frias J, Baum S, Tetri B, Bansal M \& Taub R. MGL-3196, a selective thyroid hormone receptor-beta agonist significantly decreases hepatic fat in NASH patients at 12 weeks, the primary endpoint in a 36 week serial liver biopsy study. Journal of Hepatology 201868 S38-S38. (https://doi. org/10.1016/S0168-8278(18)30292-7).

96 Perra A, Simbula G, Simbula M, Pibiri M, Kowalik MA, Sulas P, Cocco MT, Ledda-Columbano GM \& Columbano A. Thyroid hormone (T3) and TRbeta agonist GC-1 inhibit/reverse nonalcoholic fatty liver in rats. FASEB Journal 200822 2981-2989. (https://doi. org/10.1096/fj.08-108464).

97 Cable EE, Finn PD, Stebbins JW, Hou J, Ito BR, van Poelje PD, Linemeyer DL \& Erion MD. Reduction of hepatic steatosis in rats and mice after treatment with a liver-targeted thyroid hormone receptor agonist. Hepatology 200949 407-417. (https://doi.org/10.1002/ hep.22572).

98 Basaria S. Male hypogonadism. Lancet 2014383 1250-1263. (https:// doi.org/10.1016/S0140-6736(13)61126-5).

99 Mody A, White D, Kanwal F \& Garcia JM. Relevance of low testosterone to non-alcoholic fatty liver disease. Cardiovascular Endocrinology 20154 83-89. (https://doi.org/10.1097/ XCE.0000000000000057)

100 Eguchi Y, Eguchi T, Mizuta T, Ide Y, Yasutake T, Iwakiri R, Hisatomi A, Ozaki I, Yamamoto K, Kitajima Y, et al. Visceral fat accumulation and insulin resistance are important factors in nonalcoholic fatty liver disease. Journal of Gastroenterology $2006 \mathbf{4 1}$ 462-469. (https://doi. org/10.1007/s00535-006-1790-5).

101 Wang C, Jackson G, Jones TH, Matsumoto AM, Nehra A, Perelman MA, Swerdloff RS, Traish A, Zitzmann M \&
Cunningham G. Low testosterone associated with obesity and the metabolic syndrome contributes to sexual dysfunction and cardiovascular disease risk in men with type 2 diabetes. Diabetes Care 201134 1669-1675. (https://doi.org/10.2337/dc10-2339).

102 Jaruvongvanich V, Sanguankeo A, Riangwiwat T \& Upala S. Testosterone, sex hormone-binding globulin and nonalcoholic fatty liver disease: a systematic review and meta-analysis. Annals of Hepatology 201716 382-394. (https://doi. org/10.5604/16652681.1235481).

103 Seo NK, Koo HS, Haam JH, Kim HY, Kim MJ, Park KC, Park KS \& Kim YS. Prediction of prevalent but not incident non-alcoholic fatty liver disease by levels of serum testosterone. Journal of Gastroenterology \& Hepatology 201530 1211-1216. (https://doi. org/10.1111/jgh.12935).

104 Kim S, Kwon H, Park JH, Cho B, Kim D, Oh SW, Lee CM \& Choi HC A low level of serum total testosterone is independently associated with nonalcoholic fatty liver disease. BMC Gastroenterology 201212 69. (https://doi.org/10.1186/1471-230X-12-69).

105 Sakr HF, Hussein AM, Eid EA \& AlKhateeb M. Possible mechanisms underlying fatty liver in a rat model of male hypogonadism: a protective role for testosterone. Steroids 2018135 21-30. (https://doi. org/10.1016/j.steroids.2018.04.004).

106 Schleich F \& Legros JJ. Effects of androgen substitution on lipid profile in the adult and aging hypogonadal male. European Journal of Endocrinology 2004151 415-424. (https://doi.org/10.1530/ eje.0.1510415).

107 Zhang H, Liu Y, Wang L, Li Z, Zhang H, Wu J, Rahman N, Guo Y, Li D, Li N, et al. Differential effects of estrogen/androgen on the prevention of nonalcoholic fatty liver disease in the male rat. Journal of Lipid Research $2013 \mathbf{5 4}$ 345-357. (https://doi.org/10.1194/jlr. M028969).

108 Nikolaenko L, Jia Y, Wang C, Diaz-Arjonilla M, Yee JK, French SW, Liu PY, Laurel S, Chong C, Lee K, et al. Testosterone replacement ameliorates nonalcoholic fatty liver disease in castrated male rats. Endocrinology 2014155 417-428. (https://doi.org/10.1210/en.20131648).

109 Hoyos CM, Yee BJ, Phillips CL, Machan EA, Grunstein RR \& Liu PY. Body compositional and cardiometabolic effects of testosterone therapy in obese men with severe obstructive sleep apnoea: a randomised placebo-controlled trial. European Journal of Endocrinology 2012167 531-541. (https://doi.org/10.1530/EJE-12-0525).

110 Huang G, Bhasin S, Tang ER, Aakil A, Anderson SW, Jara H, Davda M, Travison TG \& Basaria S. Effect of testosterone administration on liver fat in older men with mobility limitation: results from a randomized controlled trial. Journals of Gerontology. Series A, Biological Sciences and Medical Sciences 201368 954-959. (https://doi. org/10.1093/gerona/gls259).

111 Hwang K \& Miner M. Controversies in testosterone replacement therapy: testosterone and cardiovascular disease. Asian Journal of Andrology 201517 187-191. (https://doi.org/10.4103/1008682X.146968).

112 Moller N \& Jorgensen JO. Effects of growth hormone on glucose, lipid, and protein metabolism in human subjects. Endocrine Reviews 200930 152-177. (https://doi.org/10.1210/er.2008-0027).

113 Kargi AY \& Merriam GR. Diagnosis and treatment of growth hormone deficiency in adults. Nature Reviews. Endocrinology 20139 335-345. (https://doi.org/10.1038/nrendo.2013.77).

114 Gazzaruso C, Gola M, Karamouzis I, Giubbini R \& Giustina A. Cardiovascular risk in adult patients with growth hormone (GH) deficiency and following substitution with GH--an update. Journal of Clinical Endocrinology \& Metabolism 201499 18-29. (https://doi. org/10.1210/jc.2013-2394).

115 Ichikawa T, Nakao K, Hamasaki K, Furukawa R, Tsuruta S, Ueda Y, Taura N, Shibata H, Fujimoto M, Toriyama K, et al. Role of growth hormone, insulin-like growth factor 1 and insulin-like growth factor-binding protein 3 in development of non-alcoholic fatty

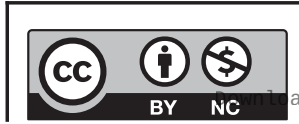

This work is licensed under a Creative Commons Attribution-NonCommercial 4.0 International License. ded from Bioscientifica.com at 04/26/2023 02:09:00PM 
liver disease. Hepatology International 20071 287-294. (https://doi. org/10.1007/s12072-007-9007-4).

116 Morselli LL, Nedeltcheva A, Leproult R, Spiegel K, Martino E, Legros JJ, Weiss RE, Mockel J, Van Cauter E \& Copinschi G. Impact of GH replacement therapy on sleep in adult patients with GH deficiency of pituitary origin. European Journal of Endocrinology 2013 168 763-770. (https://doi.org/10.1530/EJE-12-1037).

117 Ichikawa T, Hamasaki K, Ishikawa H, Ejima E, Eguchi K \& Nakao K. Non-alcoholic steatohepatitis and hepatic steatosis in patients with adult onset growth hormone deficiency. Gut 200352 914. (https:// doi.org/10.1136/gut.52.6.914).

118 Fusco A, Miele L, D'Uonnolo A, Forgione A, Riccardi L, Cefalo C, Barini A, Bianchi A, Giampietro A, Cimino V, et al. Nonalcoholic fatty liver disease is associated with increased GHBP and reduced GH/IGF-I levels. Clinical Endocrinology 201277 531-536. (https://doi. org/10.1111/j.1365-2265.2011.04291.x).

119 Fan Y, Fang X, Tajima A, Geng X, Ranganathan S, Dong H, Trucco M $\&$ Sperling MA. Evolution of hepatic steatosis to fibrosis and adenoma formation in liver-specific growth hormone receptor knockout mice. Frontiers in Endocrinology 20145 218. (https://doi. org/10.3389/fendo.2014.00218).

120 Cordoba-Chacon J, Majumdar N, List EO, Diaz-Ruiz A, Frank SJ, Manzano A, Bartrons R, Puchowicz M, Kopchick JJ \& Kineman RD. Growth hormone inhibits hepatic de novo lipogenesis in adult mice. Diabetes 201564 3093-3103. (https://doi.org/10.2337/db15-0370).

121 Matsumoto R, Fukuoka H, Iguchi G, Nishizawa H, Bando H, Suda K, Takahashi M \& Takahashi Y. Long-term effects of growth hormone replacement therapy on liver function in adult patients with growth hormone deficiency. Growth Hormone \& IGF Research 201424 174-179. (https://doi.org/10.1016/j.ghir.2014.07.002).

122 Nishizawa H, Iguchi G, Fukuoka H, Takahashi M, Suda K, Bando H, Matsumoto R, Yoshida K, Odake Y, Ogawa W, et al. IGF-I induces senescence of hepatic stellate cells and limits fibrosis in a p53dependent manner. Sci Rep 34605. Scientific Reports 2016634605. (https://doi.org/10.1038/srep34605).

123 Franco C, Brandberg J, Lonn L, Andersson B, Bengtsson BA \& Johannsson G. Growth hormone treatment reduces abdominal visceral fat in postmenopausal women with abdominal obesity: a 12-month placebo-controlled trial. Journal of Clinical Endocrinology \& Metabolism 200590 1466-1474. (https://doi.org/10.1210/jc.20041657).

124 Clemmons DR. Roles of insulin-like growth factor-I and growth hormone in mediating insulin resistance in acromegaly. Pituitary 20025 181-183. (https://doi.org/10.1023/a:1023321421760).

125 Olarescu NC \& Bollerslev J. The impact of adipose tissue on insulin resistance in acromegaly. Trends in Endocrinology \& Metabolism 2016 27 226-237. (https://doi.org/10.1016/j.tem.2016.02.005).

126 Koutsou-Tassopoulou A, Papapostoli-Sklavounou I, Krawczyk M, Friesenhahn-Ochs B, Weber SN, Lammert F \& Stokes CS. Hepatic steatosis in patients with acromegaly. Endocrinology, Diabetes \& Metabolism 20192 e00090. (https://doi.org/10.1002/edm2.90).

127 Ciresi A, Guarnotta V, Campo D \& Giordano C. Hepatic steatosis index in acromegaly: correlation with insulin resistance regardless of the disease control. International Journal of Endocrinology 20182018 5421961. (https://doi.org/10.1155/2018/5421961).

128 Woods CP, Hazlehurst JM \& Tomlinson JW. Glucocorticoids and non-alcoholic fatty liver disease. Journal of Steroid Biochemistry \& Molecular Biology 2015154 94-103. (https://doi.org/10.1016/j. jsbmb.2015.07.020).

129 Rockall AG, Sohaib SA, Evans D, Kaltsas G, Isidori AM, Monson JP, Besser GM, Grossman AB \& Reznek RH. Hepatic steatosis in Cushing's syndrome: a radiological assessment using computed tomography. European Journal of Endocrinology 2003149 543-548. (https://doi.org/10.1530/eje.0.1490543).

130 Auer MK, Stalla GK \& Stieg MR. Investigating the role of cortisol and growth hormone in fatty liver development: fatty liver index in patients with pituitary adenomas. Pituitary 201619 461-471. (https://doi.org/10.1007/s11102-016-0726-1).

131 Targher G, Bertolini L, Zoppini G, Zenari L \& Falezza G. Relationship of non-alcoholic hepatic steatosis to cortisol secretion in dietcontrolled Type 2 diabetic patients. Diabetic Medicine 200522 1146-1150. (https://doi.org/10.1111/j.1464-5491.2005.01583.x).

132 Hubel JM, Schmidt SA, Mason RA, Haenle MM, Oeztuerk S, Koenig W, Boehm BO, Kratzer W, Graeter T, Flechtner-Mors M, et al. Influence of plasma cortisol and other laboratory parameters on nonalcoholic Fatty liver disease. Hormone and Metabolic Research 2015 47 479-484. (https://doi.org/10.1055/s-0034-1389982).

133 Gariani K, Marques-Vidal P, Waeber G, Vollenweider P \& Jornayvaz FR. Salivary cortisol is not associated with incident insulin resistance or type 2 diabetes mellitus. Endocrine Connections 20198 870-877. (https://doi.org/10.1530/EC-19-0251).

134 Wake DJ, Rask E, Livingstone DE, Soderberg S, Olsson T \& Walker BR. Local and systemic impact of transcriptional up-regulation of 11beta-hydroxysteroid dehydrogenase type 1 in adipose tissue in human obesity. Journal of Clinical Endocrinology \& Metabolism 200388 3983-3988. (https://doi.org/10.1210/jc.2003-030286).

135 Morgan SA, McCabe EL, Gathercole LL, Hassan-Smith ZK, Larner DP, Bujalska IJ, Stewart PM, Tomlinson JW \& Lavery GG. 11beta-HSD1 is the major regulator of the tissue-specific effects of circulating glucocorticoid excess. Proceedings of the National Academy of Sciences of the United States of America 2014111 E2482-E2491. (https://doi. org/10.1073/pnas.1323681111).

136 Hermanowski-Vosatka A, Balkovec JM, Cheng K, Chen HY, Hernandez M, Koo GC, Le Grand CB, Li Z, Metzger JM, Mundt SS, et al. 11beta-HSD1 inhibition ameliorates metabolic syndrome and prevents progression of atherosclerosis in mice. Journal of Experimental Medicine 2005202 517-527. (https://doi.org/10.1084/ jem.20050119).

137 Anderson A \& Walker BR. Anderson A \& Walker BR. 11beta-HSD1 inhibitors for the treatment of type 2 diabetes and cardiovascular disease. Drugs 201373 1385-1393. (https://doi.org/10.1007/s40265013-0112-5)

138 Ahmed A, Rabbitt E, Brady T, Brown C, Guest P, Bujalska IJ, Doig C, Newsome PN, Hubscher S, Elias E, et al. A switch in hepatic cortisol metabolism across the spectrum of non alcoholic fatty liver disease. PLOS ONE 20127 e29531. (https://doi.org/10.1371/journal. pone.0029531).

139 Hazlehurst JM, Oprescu AI, Nikolaou N, Di Guida R, Grinbergs AE, Davies NP, Flintham RB, Armstrong MJ, Taylor AE, Hughes BA, et al. Dual-5alpha-Reductase inhibition promotes hepatic lipid accumulation in man. Journal of Clinical Endocrinology \& Metabolism 2016101 103-113. (https://doi.org/10.1210/jc.2015-2928).

140 Targher G, Bertolini L, Scala L, Cigolini M, Zenari L, Falezza G \& Arcaro G. Associations between serum 25-hydroxyvitamin D3 concentrations and liver histology in patients with non-alcoholic fatty liver disease. Nutrition, Metabolism, and Cardiovascular Diseases 200717 517-524. (https://doi.org/10.1016/j.numecd.2006.04.002).

141 Barchetta I, Angelico F, Del Ben M, Baroni MG, Pozzilli P, Morini S \& Cavallo MG. Strong association between non alcoholic fatty liver disease (NAFLD) and low 25(OH) vitamin D levels in an adult population with normal serum liver enzymes. BMC Medicine 20119 85. (https://doi.org/10.1186/1741-7015-9-85).

142 Eliades M, Spyrou E, Agrawal N, Lazo M, Brancati FL, Potter JJ, Koteish AA, Clark JM, Guallar E \& Hernaez R. Meta-analysis: vitamin $\mathrm{D}$ and non-alcoholic fatty liver disease. Alimentary Pharmacology \& Therapeutics 201338 246-254. (https://doi.org/10.1111/apt.12377).

143 Pittas AG, Sun Q, Manson JE, Dawson-Hughes B \& Hu FB. Plasma 25-hydroxyvitamin $\mathrm{D}$ concentration and risk of incident type 2 diabetes in women. Diabetes Care 201033 2021-2023. (https://doi. org/10.2337/dc10-0790).

144 Marques-Vidal P, Vollenweider P, Guessous I, Henry H, Boulat O, Waeber G \& Jornayvaz FR. Serum vitamin D concentrations are not

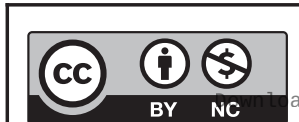

This work is licensed under a Creative Commons Attribution-NonCommercial 4.0 International License. ded from Bioscientifica com at 04/26/2023 02:09: 0०PM 
associated with insulin resistance in Swiss adults. Journal of Nutrition 2015145 2117-2122. (https://doi.org/10.3945/jn.115.211763).

145 Zhou QG, Hou FF, Guo ZJ, Liang M, Wang GB \& Zhang X. 1,25-Dihydroxyvitamin D improved the free fatty-acid-induced insulin resistance in cultured C2C12 cells. Diabetes/Metabolism Research \& Reviews 200824 459-464. (https://doi.org/10.1002/ dmrr.873).

146 Abramovitch S, Dahan-Bachar L, Sharvit E, Weisman Y, Ben Tov A, Brazowski E \& Reif S. Vitamin D inhibits proliferation and profibrotic marker expression in hepatic stellate cells and decreases thioacetamide-induced liver fibrosis in rats. Gut 201160 1728-1737. (https://doi.org/10.1136/gut.2010.234666).

147 Zhang H, Shen Z, Lin Y, Zhang J, Zhang Y, Liu P, Zeng H, Yu M, Chen $X$, Ning L, et al. Vitamin D receptor targets hepatocyte nuclear factor 4alpha and mediates protective effects of vitamin D in nonalcoholic fatty liver disease. Journal of Biological Chemistry 2020 295 3891-3905. (https://doi.org/10.1074/jbc.RA119.011487).

148 von Hurst PR, Stonehouse W \& Coad J. Vitamin D supplementation reduces insulin resistance in South Asian women living in New Zealand who are insulin resistant and vitamin D deficient - a randomised, placebo-controlled trial. British Journal of Nutrition 2010 103 549-555. (https://doi.org/10.1017/S0007114509992017).

149 Farag HAM, Hosseinzadeh-Attar MJ, Muhammad BA, Esmaillzadeh A \& Hamid El Bilbeisi A. Effects of vitamin D supplementation along with endurance physical activity on lipid profile in metabolic syndrome patients: a randomized controlled trial. Diabetes \& Metabolic Syndrome 201913 1093-1098. (https://doi.org/10.1016/j. dsx.2019.01.029).

150 Ferreira PP, Cangussu L, Bueloni-Dias FN, Orsatti CL, Schmitt EB, Nahas-Neto J \& Nahas EAP. Vitamin D supplementation improves the metabolic syndrome risk profile in postmenopausal women. Climacteric 202023 24-31. (https://doi.org/10.1080/13697137.2019. 1611761).

151 Cui R, Sheng H, Rui XF, Cheng XY, Sheng CJ, Wang JY \& Qu S. Low bone mineral density in Chinese adults with nonalcoholic fatty liver disease. International Journal of Endocrinology 20132013396545. (https://doi.org/10.1155/2013/396545).

152 Lee SH, Yun JM, Kim SH, Seo YG, Min H, Chung E, Bae YS, Ryou IS \& Cho B. Association between bone mineral density and nonalcoholic fatty liver disease in Korean adults. Journal of Endocrinological Investigation 201639 1329-1336. (https://doi.org/10.1007/s40618016-0528-3).

153 Moon SS, Lee YS \& Kim SW. Association of nonalcoholic fatty liver disease with low bone mass in postmenopausal women. Endocrine 201242 423-429. (https://doi.org/10.1007/s12020-012-9639-6).
154 Mantovani A, Dauriz M, Gatti D, Viapiana O, Zoppini G, Lippi G, Byrne CD, Bonnet F, Bonora E \& Targher G. Systematic review with meta-analysis: non-alcoholic fatty liver disease is associated with a history of osteoporotic fractures but not with low bone mineral density. Alimentary Pharmacology \& Therapeutics 201949 375-388. (https://doi.org/10.1111/apt.15087).

155 Hannemann A \& Wallaschofski H. Prevalence of primary aldosteronism in patient's cohorts and in population-based studies--a review of the current literature. Hormone and Metabolic Research 2012 44 157-162. (https://doi.org/10.1055/s-0031-1295438).

156 Giacchetti G, Ronconi V, Turchi F, Agostinelli L, Mantero F, Rilli S $\&$ Boscaro M. Aldosterone as a key mediator of the cardiometabolic syndrome in primary aldosteronism: an observational study. Journal of Hypertension 200725 177-186. (https://doi.org/10.1097/ HJH.0b013e3280108e6f).

157 Luther JM. Effects of aldosterone on insulin sensitivity and secretion. Steroids 201491 54-60. (https://doi.org/10.1016/j. steroids.2014.08.016)

158 Sowers JR, Whaley-Connell A \& Epstein M. Narrative review: the emerging clinical implications of the role of aldosterone in the metabolic syndrome and resistant hypertension. Annals of Internal Medicine 2009150 776-783. (https://doi.org/10.7326/0003-4819150-11-200906020-00005).

159 Srinivasa S, Fitch KV, Quadri N, Maehler P, O'Malley TK, MartinezSalazar EL, Burdo TH, Feldpausch M, Torriani M, Adler GK, et al. Significant association of aldosterone and liver fat among HIVinfected individuals with metabolic dysregulation. Journal of the Endocrine Society 20182 1147-1157. (https://doi.org/10.1210/js.201800194).

160 Luo P, Dematteo A, Wang Z, Zhu L, Wang A, Kim HS, Pozzi A, Stafford JM \& Luther JM. Aldosterone deficiency prevents high-fatfeeding-induced hyperglycaemia and adipocyte dysfunction in mice. Diabetologia 201356 901-910. (https://doi.org/10.1007/s00125-0122814-8).

161 Shibayama Y, Wada N, Baba S, Obara S, Sakai H, Usubuchi H, Terae S, Nakamura A \& Atsumi T. The risk factors for hepatic steatosis in patients with primary aldosteronism. Endocrine Journal 202067 623-629. (https://doi.org/10.1507/endocrj.EJ19-0600).

162 Zhang P, Ge Z, Wang H, Feng W, Sun X, Chu X, Jiang C, Wang Y, Zhu D \& Bi Y. Prolactin improves hepatic steatosis via CD36 pathway. Journal of Hepatology 201868 1247-1255. (https://doi. org/10.1016/j.jhep.2018.01.035).

163 Zhang P, Feng W, Chu X, Sun X, Zhu D \& Bi Y. A newly noninvasive model for prediction of non-alcoholic fatty liver disease: utility of serum prolactin levels. BMC Gastroenterology 201919 202. (https:// doi.org/10.1186/s12876-019-1120-z).

Received in final form 18 December 2020

Accepted 6 January 2021

Accepted Manuscript published online 8 January 2021 https://ec.bioscientifica.com https://doi.org/10.1530/EC-20-0490 (c) 2021 The authors Published by Bioscientifica Ltd

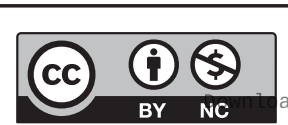

This work is licensed under a Creative Commons Attribution-NonCommercial 4.0 International License. ded from Bioscientifica.com at 04/26/2023 02:09:0๑PM 